\title{
A PRECARIZAÇÃO DO TRABALHO DOCENTE EM UNIVERSIDADES PÚBLICAS BRASILEIRAS
}

\author{
Paulo de Oliveira Perna ${ }^{1}$
}

Na última década, vêm se avolumando estudos, análises e críticas às transformações do mundo do trabalho, caracterizando uma cisão cada vez mais pronunciada: de um lado, o trabalho executado com todo o suporte tecnológico, com disponibilidade de recursos humanos, com a melhoria da qualificação geral dos profissionais, mas que, no entanto, está restrito a poucos processos produtivos; e por outro, atingindo a maioria da população, o trabalho intensificado, precarizado, e para o qual se exige pouca ou até mesmo nenhuma qualificação.

Esta divisão diz respeito ao conjunto do mundo globalizado, onde alguns poucos países usufruem de uma boa condição socioeconômica, com o suporte ótimo da produção de bens e serviços, enquanto os demais - a maioria - tem que produzir em condições pouco satisfatórias e, além disso, produzir para atender tanto suas próprias demandas, bem como as dos países que capitaneiam a economia mundial. Essa é, em outros termos, a dinâmica do modo capitalista de produção, com suas contradições cada vez mais amadurecidas, tal qual já tinham sido analisadas há mais de um século, por Karl Marx.

As transformações do mundo do trabalho, produzindo resultados tão diversos, vão se desdobrar em desigualdades que estão presentes em todos os âmbitos da vida social. Não poderia, portanto, ser diferente para o dia a dia das universidades públicas brasileiras.

Notadamente a partir do advento da era neoliberal, no início dos anos 1990, vêm-se avolumando o mal-estar no mundo acadêmico. Por um lado, a existência de poucos "centros de excelência", providos de recursos em quantidade e qualidade suficientes para o desempenho de suas atividades, enquanto a maioria das instituições públicas de ensino superior enfrenta um expressivo desfinanciamento, cujos resultados têm levado a desdobramentos funestos.

$\mathrm{Na}$ tentativa de recuperar sua condição de trabalho, essas instituições e seus servidores - docentes e corpo técnico-administrativo - se vêem forçados à árdua tarefa de captação de recursos, o que acaba, em última instância, mercantilizando a vida universitária.

Por outro lado, as diretrizes que emanam dos órgãos normatizadores da vida universitária no país - CAPES e CNPQ - parecem não tomar conhecimento dessas contradições, passando a exigir resultados incompatíveis com o quadro já apontado.

Um exemplo disso é a adoção de critérios quantitativistas para classificar e avaliar a produção docente, o que, por sua vez, serve de parâmetros para a alocação de recursos financeiros. Para alcançar esse nível de produtividade, professores, alunos orientandos, bolsistas, etc. são levados à inserção, a qualquer preço, nos programas de pós-graduação, orientados por uma meta que já se tornou obsessiva: aumento do número de artigos, do número de orientações, da produção de livros ou capítulos em livros, etc., de modo a ter rendimentos ótimos nas "bolsas produtividade em pesquisa".

Assim, também cresce o nível de competição entre os periódicos pelos melhores trabalhos, o que em si é um fato altamente benéfico à ciência brasileira. O que se deve lembrar, no entanto, é que a crescente demanda por produção de qualidade não se faz acompanhar de igual crescimento - como já se frisou - das condições de ensino/pesquisa/ extensão, tanto da graduação como da pós-graduação. Cada vez mais, as revistas científicas são "obrigadas" a obter um resultado que não encontra respaldo em infraestrutura correspondente.

Por outro lado, um dos indicadores mais sensíveis desta complexa questão tem sido os efeitos deletérios à saúde dos docentes, cada vez mais presentes como objeto de pesquisas, artigos, livros, e outros.

Não é preciso muito esforço para prever os resultados de tal dinâmica para o processo de trabalho docente de nível superior: rebaixamento da qualidade científica da produção e, o que é mais grave, do aumento do desgaste e sofrimento mental dos envolvidos.

Portanto, a superação deste mal-estar geral deve fazer parte do plano de lutas da categoria docente, sem o que, se pode prever níveis de adoecimento e de banalização da prática científica incompatíveis com o compromisso social das Universidades Públicas.

'Enfermeiro. Mestre em Enfermagem. Professor do Departamento de Enfermagem da Universidade Federal do Paraná. Líder do Núcleo de Estudos em Saúde Coletiva - NESC. Revisor da Revista Cogitare Enfermagem. 


\title{
THE PRECARIZATION OF TEACHING WORK IN BRAZILIAN STATE UNIVERSITIES
}

\author{
Paulo de Oliveira Perna ${ }^{1}$
}

In the last decade, studies, analyses and criticism of the transformations in the world of work have grown in volume, characterising an increasingly pronounced split; on the one hand, work carried out with technical support, with human resources available, with the bettering of the general qualifications of the professionals involved, but which nevertheless is restricted to a few productive processes; and on the other, affecting the majority of the population, work which is intensified and precarized and which requires little or even no qualification.

This division is a result of its globalization, where a few countries benefit from a good socioeconomic condition, with great support of goods and services, while the others - the majority - have to produce in unsatisfactory conditions and, apart from that, have to produce to satisfy not only their own needs but also those of the countries which command the world economy. This is, in other terms, the dynamic of the capitalist mode of production, with its ever more mature contradictions, as they were analyzed more than a century ago by Karl Marx.

The transformations in the world of work, producing such diverse results, will unfold in disequalities present in all fields of social life. It could not, therefore, be any different for the day-to-day of Brazilian State Universities.

Uneasiness has been growing in the academic world, notably since the advent of the neo-liberal era in the early nineties. While a few 'centers of excellence' are provided with resources of a quality and quantity that are sufficient for the performance of their activities, the majority of state higher education institutions face a deliberate process of definancing, whose results have led to dismal consequences.

In an attempt to salvage their working conditions, these institutions and their staff - teachers and the technical-administrative body - find themselves forced to the arduous task of obtaining funding and resources from elsewhere, which at the end of the day ends up merchantilizing university life.

On the other hand, the directives which emanate from the organs which standardize Brazilian university life - CAPES and CNPQ - appear to ignore these contradictions, demanding instead results which are incompatible with the picture as described above.

One example of this is the adoption of quantitativist criteria for classifying and evaluating the publications of the teaching staff, which, in turn, serves as a parameter for the future allocation of resources. In order to reach this level of productivity, professors, students under supervision, scholarship students etc are led to insertion, at any price, in the post-graduate programs, guided by a goal which has become obsessive: an increase in the number of articles, in the number of students being tutored or supervised, in the production of books or chapters in books, such that there should be great yields from the funds earmarked for research.

Thus, competition also grows between the periodicals for the best works, which in itself is of great benefit to Brazilian academic knowledge production. What one should remember, however, is that the growing demand for quality production has not been accompanied by equal growth, as has been emphasized, in teaching/research/ extension courses' conditions, as much in undergraduate as post-graduate courses. More and more, scientific magazines are 'obliged' to obtain results which are not backed up by corresponding infrastructure.

On the other hand, one of the most sensitive indicators of this complex question has been the deleterious effect on the health of the teaching body, ever more present as the subject of research, articles, books and so on.

It does not take much effort to foresee the results of this dynamic on the work processes of higher education teaching staff; lowering of the quality of scientific production and, which is worse, an increase in burnout and mental suffering among those involved.

Therefore, overcoming this general sense of discomfort must form part of the academic staff's battle plan. Otherwise one may predict levels of sickness and banalization of academic literature production which are incompatible with the social contract of State Universities.

${ }^{1}$ Nurse. M.A. in Nursing. Professor of the Department of Nursing at the Federal University of Paraná. Leader of the Collective Health Study Group (NESC, in Portuguese). Reviewer of the Cogitare Enfermagem magazine.

Cogitare Enferm. 2011 Out/Dez; 16(4):605-7 


\title{
LA PRECARIZACIÓN DEL TRABAJO DOCENTE EN UNIVERSIDADES PÚBLICAS BRASILEÑAS
}

\author{
Paulo de Oliveira Perna ${ }^{1}$
}

En la última década, estudios, análisis y críticas acerca de las transformaciones del mundo del trabajo han crecido muchísimo, caracterizando una cisura cada vez mayor: de un lado, el trabajo ejecutado con soporte tecnológico, con disponibilidad de recursos humanos, con mejoría en la calificación general de los profesionales, pero, sin embargo, restricto a pocos procesos productivos; de otro lado, abarcando la mayoría de la población, el trabajo intensificado, precarizado, y para lo cual se exige poca o ninguna calificación.

Esta división se refiere al conjunto del mundo globalizado, donde algunos pocos países disfrutan de una buena condición socioeconómica, con gran soporte de la producción de bienes y servicios, mientras los demás - la mayoría - debe producir en condiciones poco satisfactorias, además de producir para atender tanto a sus propias demandas, cuanto a las de los países que dominan la economía mundial. Esa es, en otros términos, la dinámica del modo capitalista de producción, con sus contradicciones cada vez mayores, como ya se había analizado más de un século antes por Karl Marx.

Los cambios del mundo del trabajo, produciendo resultados muy diversos, resultan en desigualdades que están en todos los ámbitos de la vida social. Así, no podría ser diferente para el día a día de las universidades públicas brasileñas.

A partir de la llegada de la era neoliberal, en el inicio de los años 1990, viene creciendo el malestar en el mundo académico. Por un lado, la existencia de pocos "centros de excelencia", con recursos en cantidad y cualidad suficientes para el desempeño de sus actividades, mientras, por otro, la mayoría de las instituciones públicas de enseñanza superior pasa por un expresivo "desfinanciamiento", cuyos resultados traen consecuencias funestas.

En la tentativa de recuperar su condición de trabajo, esas instituciones y sus servidores - docentes y personal técnico-administrativo - se sienten obligados a la ardua tarea de captar recursos, lo que resulta, en última instancia, en la mercantilización de la vida universitaria.

Las orientaciones que vienen de las instituciones normatizadoras de la vida universitaria en el país - CAPES y CNPQ - parecen no atentar a esas contradicciones, pasando a exigir resultados incompatibles con el cuadro apuntado.

Un ejemplo es la adopción de criterios cuantitativistas para clasificar y evaluar la producción docente, lo que sirve de parámetro para la distribución de recursos financieros. Para llegar a el nivel de productividad deseado, profesores, alumnos, orientandos, becarios, etc. son levados a la inserción, a cualquier precio, en los programas de posgrado, orientados por una meta que se volvió obsesiva: aumento del número de artículos, del número de orientaciones, de la producción de libros o capítulos en libros, etc., de modo a obtener ótimos resultados en las "becas de productividad en investigación".

Además, también crece el nivel de competición entre los periódicos por los mejores trabajos, lo que representa un hecho muy benéfico a la ciencia brasileña. Sin embargo, lo que se debe lembrar es que la creciente demanda por producción de calidad no acompaña ese crescimiento - como fue dicho - de las condiciones de enseñanza/ investigación/extensión, tanto de la graduación como del posgrado. Cada vez más, las revistas científicas son "obligadas" a obtener un resultado que no tiene respaldo en infraestructura correspondiente.

Por otro lado, uno de los indicadores más sensibles de esta compleja cuestión tienen sido los efectos deletéreos a la salud de los docentes, cada vez más presentes como objeto de investigaciones, artículos, libros, etc.

No se necesita mucho esfuerzo para prevenir los resultados de esa dinámica para el proceso de trabajo docente de nivel superior: caída de la calidad científica de la producción y, lo que es más grave, del aumento del desgaste y sufrimiento mental de los involucrados.

Por lo tanto, la superación de este malestar general debe hacer parte del plan de objetivos de la categoría docente, pues, del contrario, hay la previsión de niveles de enfermedad y de banalización de la práctica científica incompatibles con el compromiso social de las Universidades Públicas.

${ }^{1}$ Enfermero. Mestre en Enfermería. Profesor del Departamento de Enfermería de la Universidad Federal de Paraná. Jefe del Núcleo de Estudios en Salud Colectiva - NESC. Revisor de la Revista Cogitare Enfermagem 